\title{
Sustainability of Swiss Fiscal Policy
}

\author{
Gebhard Kirchgässner and Silika Prohl*
}

Keywords: Sustainability, Budget Deficit; Cointegration, Structural Breaks JEL-Classification: H62, H63

\section{Introduction}

Recent deterioration of the fiscal position of governments in several European countries and the U.S. has drawn attention to the long-run fiscal sustainability of public finance. Several theoretical approaches have been developed to analyse whether the government can manage the budget deficit in the long run. The seminal paper by Domar (1944) does not use the term sustainability but implicitly defines it as a constant long-run relation between total public debt and GDP: public debt may grow but it should not grow faster than GDP. This is, by the way, so far also the most natural definition of sustainability of public finances. It allows for a permanent public deficit, but this should also not grow faster than GDP.

While Domar (1944) considers the steady-state long-run equilibrium, more recent approaches look at the intertemporal budget constraint. The rather popular Generational Accounting Approach introduced by Auerbach, Gokнale and Kotlikoff $(1991,1992)$ defines it in terms of net fiscal burden of current and future generations. This implies that fiscal policy is sustainable whenever the

* Final Version, December 2007. - Previous versions of this paper have been presented at the CESifo Area Conference on Macro, Money and International Finance, Munich, 24 February 2006, as well as at the Annual Meeting of the Swiss Society for Economics and Statistics, Lugano, 10 March 2006. - We are grateful for helpful comments and suggestions by ULRICH MülLER and Friedrich SCHneider and an anonymous referee. We gratefully acknowledge financial support from the Research Commission of the University of St. Gallen. We thank Elsbeth Etter, Dr. Carsten Colombier and Alain Geier (Swiss Federal Finance Administration), Rolf Beyerler and Gilbert Vez (Swiss Federal Statistical Office) as well as Stefanie Schnyder (Swiss National Bank) for helping us in compiling the data.

Mailing Address: Prof. Dr. Gebhard Kirchgässner, University of St. Gallen, SIAW-HSG, Bodanstrasse 8, CH-9000 St. Gallen. Gebhard.Kirchgaessner@unisg.ch 
net debt of the government does not exceed the sum of the discounted net taxes, which should be paid by current and future generations. ${ }^{1}$

Another concept, which is more closely related to Domar (1944), defines fiscal policy as sustainable if the present value budget constraint of the government is valid: the discounted value of public debt should converge to zero at the limit. This implies that current and discounted future surpluses must be sufficient to pay off the current public debt. Following this view, several econometric tests have been developed in the empirical literature. One line proposes that the stationarity of public debt indicates the long-run sustainability of fiscal policy. Assuming constant interest rates, Нamilton and Flavin (1986) test for the stationarity of undiscounted public debt and show that the U.S. fiscal policy is consistent with the present-value budget constraint. If the discounted debt series is used, WILCOX (1989), however, shows that U.S. fiscal policy violates the intertemporal budget constraint. Another direction assumes sustainability to be given when the budget deficit and public debt are co-integrated. MaCDonald (1992) employs such a co-integration test and shows that U.S. fiscal policy is not sustainable. An alternative framework implies that fiscal policy is sustainable if government revenues and expenditures are co-integrated with a co-integrating vector $[1-1]$. Trehan and Walsh (1988, 1989), Haug (1995), Ahmend and Rogers (1995), and Quintos (1995) test for sustainability by checking for the co-integration between government revenues and expenditures and show that the U.S. federal budget deficit is not sustainable. Furthermore, they find that recent changes in the structure of fiscal policy had a significant effect on the sustainability of U.S. federal finance. Several studies find structural breaks in the U.S. federal deficit in the mid-seventies or early eighties that had a significant impact on budget sustainability. ${ }^{2}$ Quintos (1995), for example, finds that legislative tax changes in the U.S. in the early eighties, like the Kemp-Roth tax cut, had a significant impact on the sustainability of the federal budget deficit. Splitting the sample into two sub-periods and assuming a structural shock in the early eighties, she shows that the U.S. federal budget deficit was sustainable during the pre-break period but violated the intertemporal budget constraint in the post-break sub-period.

1 A similar approach was proposed by Blanchard et al. (1990) as well as Blanchard (1993) and is employed by the OECD. See, for example, OECD (2002).

2 See, for example, Hamilton and Flavin (1986), Wilcox (1989), Hakkio and Rush (1991) as well as Quintos, (1995). 
While the Generational Accounting Approach has been applied to Swiss data, ${ }^{3}$ this paper is the first one to use time series methods to test for sustainability of the Swiss fiscal policy. We consider the period from 1900 to 2002 and ask whether fiscal policy was consistent with the intertemporal budget constraint. However, because of the long time-horizon it is necessary to take into account possible structural changes in the fiscal policy due to, for example, World Wars, the Great Depression, or legislative changes in the budgetary process. Thus, we look for shifts in the Swiss federal budget process that are relevant for the assessment of its sustainability.

Figure 1: Swiss Federal Expenditure and Deficit in Relation to GDP, 1900-2002

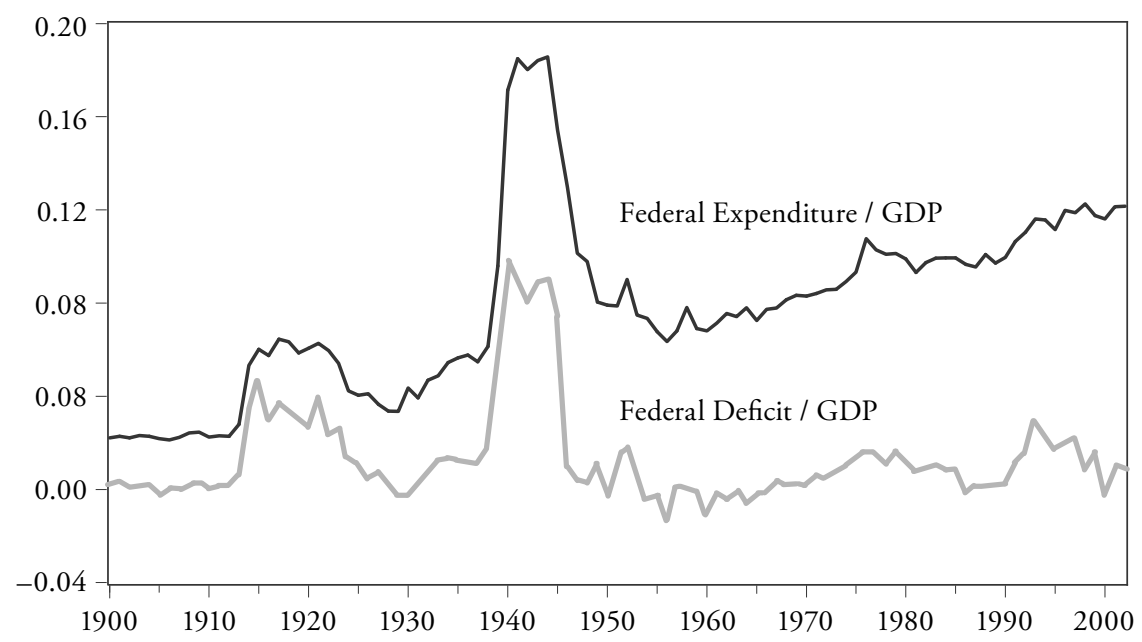

That fiscal sustainability may also be a Swiss problem can be seen from a visual examination of the historical development over the last 100 years. Figure 1 shows federal expenditure and deficit over the period from 1900 to 2002. The fiscal position of the federal government worsened substantially during both World Wars. However, the upward spike in the deficit is much more pronounced during World War II. After this war, expenditure (as a share of GDP) increased considerably, while the deficit did not show a clear picture. The development of the federal

3 See, for example, Borgman and Raffelhüschen (2004) or Kommission für KonjunkTURFRAGEN (2004). 
debt, as shown in Figure 2, on the other hand, gives a clearer picture. After the Second World War public debt accumulated during the war declined until the mid sixties, and then increased again, especially during the nineties. The federal public debt increased from 38.5 billion CHF in 1990 to 122.9 billion CHF in 2002, which implies an increase of 173 percent if measured in real terms. As a consequence, the Swiss constitution was amended by a debt brake through a referendum in December 2001, being fully effective since 2007, which - somewhat simplified - is operating in the following way: ${ }^{4}$ Expenditure has to be adjusted to the revenue which, however, is smoothed over the business cycle. In calculating this smoothed revenue, extraordinary revenue is not considered; it has to be used to pay back debt. 'Normal' surpluses and deficits are accounted in a separate account and are to be balanced over several years. Deficits which exceed six percent of the expenditure of the preceding year have to be balanced within the next three years. Extraordinary expenditure (which is not included in these calculations) can be decided on by the majority of the members in both Chambers of the Federal Parliament.

Figure 2: Swiss Federal Debt in Relation to GDP, 1900-2002

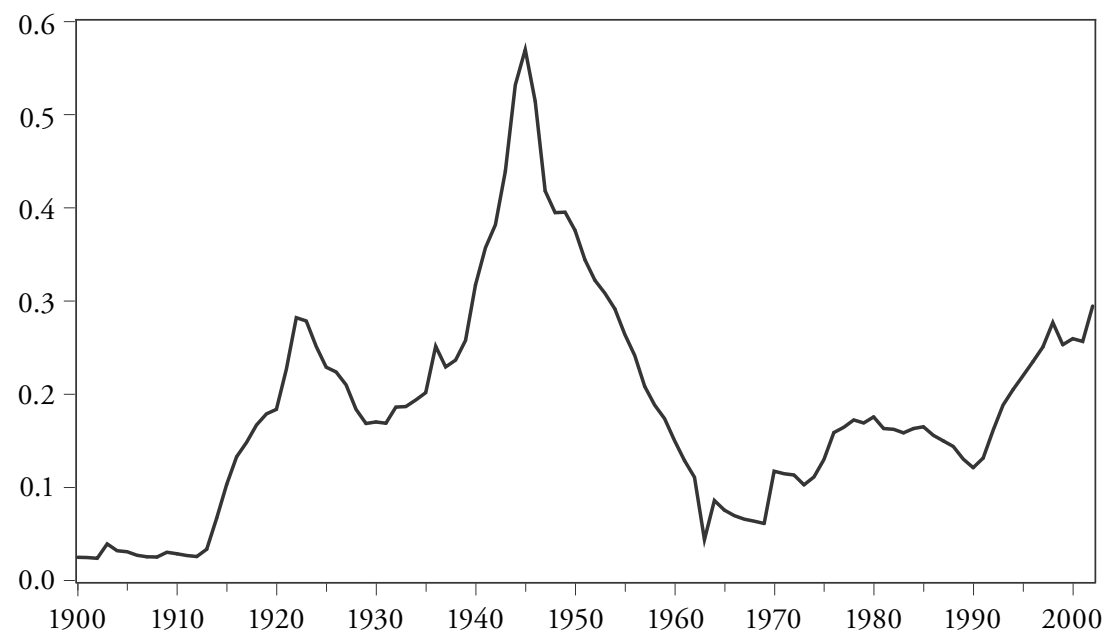

4 See also DANninger (2002) and - for more details - the legal documents: Bundesbeschluss über eine Schuldenbremse vom 22. Juni 2001 (BBl 2000, 4653) as well as Änderung des Bundesgesetzes über den eidgenössischen Finanzhaushalt vom 22. Juni 2001 (BBl 2000, 4728 f., Entwurf.). See also: Eidgenössisches Finanzdepartement (2001) as well as Bundesrat (2000, 2001). 
The fact that not only this new instrument has been introduced but that a huge majority of 84.7 percent of the people voted in favour of this amendment to the Swiss Constitution indicates that at least the Swiss population had doubts about the sustainability of its federal fiscal policy. Moreover, the generational accounting analyses for Switzerland mentioned above clearly demonstrate the existence of a sustainability gap. The problem of these analyses is, however, that they use extrapolations of the current situation and do not take into account that the current situation may not be in equilibrium. Consequently, starting with different base years the estimated sustainability gap may be quite different. The econometric approaches, on the other hand, try to look at the underlying longrun equilibrium relations and ask whether these relations imply sustainability. Their disadvantage is, however, that they might give too little weight to the most recent development (and too much to the no longer relevant past). Thus, the two approaches complement each other. As generational accounting analyses for Switzerland are available but no econometric analyses of this problem, this paper intends filling this gap. Thus, the following issue is the main concern of this study: Is the Swiss federal budget deficit consistent with the intertemporal budget constraint? And are there changes in the Swiss fiscal history which might fundamentally shift the sustainable deficit process?

To answer these questions, we use a set of tests for cointegration between federal revenues and expenditures over the period from 1900 to 2002. Searching for structural changes in the budgetary process, we employ different econometric strategies. We apply unit root tests which take account of structural breaks to the deficit, revenue and expenditure series. Furthermore, we use Chow-tests to examine the stability of the parameters of the short-run relationship between revenues and expenditures. Additionally, we perform the GREGORY and Hansen (1996) test in order to check for the presence of structural breaks in the long-run cointegration relationship between revenues and expenditures.

The paper is organised as follows: Section 2 presents the theoretical framework and the test approaches which have been developed. Section 3 contains the empirical results. It presents the results of unit root tests, tests for structural breaks, and tests for co-integration between revenues and expenditures. In Section 4, we finally discuss how the seemingly contradictory results for the entire period and the two sub-periods before and after the Second World War might be interpreted. 


\section{The Theoretical Framework}

The theoretical model is based on the budget constraint of the government that is given by

$$
G_{t}+\left(1+r_{t}\right) T D_{t-1}=R+T D_{\mathrm{t}}
$$

where $T D$ represents the stock of public debt, while $r$ denotes the interest rate for public debt, $R$ government revenues (including seignorage) and $G$ expenditures excluding interest payments.

Assuming that equation (1) holds for each period, by performing the forward substitution we obtain the intertemporal budget constraint for the period from $\tau=t$ to $\tau=T$ as $^{5}$

$$
T D_{t}=\sum_{\tau=t+1}^{T}\left[\prod_{j=1}^{\tau} \frac{1}{\left(1+r_{t+j}\right)}\left(R_{\tau}-G_{\tau}\right)\right]+\prod_{j=t}^{T-1} \frac{1}{\left(1+r_{j}\right)} T D_{T} .
$$

By assuming a constant interest rate $r$, this simplifies to

$$
T D_{t}=\sum_{\tau=t+1}^{T}\left[\frac{1}{(1+r)^{\tau-t}}\left(R_{\tau}-G_{\tau}\right)\right]+\frac{1}{(1+r)^{T-t}} T D_{T}
$$

Thus, the present-value budget constraint (PVBC) of the government is given by

$$
T D_{t}=\sum_{\tau=t+1}^{\infty}\left[\frac{1}{(1+r)^{\tau-t}}\left(R_{\tau}-G_{\tau}\right)\right]+\lim _{T \rightarrow \infty} \frac{1}{(1+r)^{T-t}} T D_{T} .
$$

Whether fiscal policy is sustainable depends on the development of the second term of this equation. If the transversality condition

$$
\lim _{T \rightarrow \infty} \frac{1}{(1+r)^{T-t}} T D_{T}=0
$$

5 See, for example, Hamilton and Flavin (1986) or Наккio and Rush (1991). 
holds, the present-value budget constraint of the government is given by

$$
T D_{t}=\sum_{\tau=t+1}^{\infty}\left[\frac{1}{(1+r)^{\tau-t}}\left(R_{\tau}-G_{\tau}\right)\right]
$$

Condition (4) is known as the "no Ponzi game" rule for public debt, it implies that the growth rate of public debt is not larger than the real interest rate. Under the usual assumption that the interest rate is larger than the growth rate of the economy, this is a necessary and sufficient condition for fiscal policy to be sustainable. ${ }^{6}$ It requires that current and discounted future surpluses must be sufficient to pay-off the current public debt. If this requirement is satisfied, fiscal policy of the government is consistent with the present-value budget constraint.

Several methods have been developed to test whether fiscal policy of government is sustainable. One direction of the studies checks whether the data are consistent with the transversality condition by examining the stationarity properties of the primary deficit. Assuming a constant real interest rate and starting with relation (2a), Hamilton and Flavin (1986) take

$$
E_{t}\left[\lim _{T \rightarrow \infty} \frac{1}{(1+r)^{T}} T D_{T}\right]=A_{0}>0
$$

as an alternative. Inserting this into (2b) leads to

$$
T D_{D}=\sum_{\tau=t+1}^{\infty}\left[\frac{1}{(1+r)^{\tau-t}}\left(R_{\tau}-G_{\tau}\right)\right]+A_{0}(1+r)^{t}
$$

Hamilton and Flavin (1986) argue that a sufficient condition for the validity of the present value budget constraint is the stationarity of the primary deficit (excluding interest payments), $G_{\tau}-R_{\tau}$. If $A_{0}=0$ in equation (6), then they expect that public debt is stationary.

6 If the real growth rate is larger than the real interest rate, relation (3) is sufficient, but not necessary, for fiscal policy to be sustainable. Following the (implicit) Domar (1944) definition that fiscal policy is sustainable whenever the long-run relation between government debt and GDP is constant, the growth rate of public debt may well be higher than the real interest rate whenever the latter is below the long-run growth rate of the economy. 
Using annual U.S. data for the period from 1962 to 1984, they apply the Augmented Dickey-Fuller test to the budget deficit series and show that the levels of public debt and the primary deficit are stationary. Based on these findings, they suggest that the U.S. federal government budget is balanced in the presentvalue terms.

However, there have been raised several critical issues concerning the hypothesis and the results presented in this study. WILCOX (1989) uses the same data to show evidence that the hypothesis developed by Hamilton and Flavin (1986) is incorrect. He demonstrates that the present-value budget constraint may be satisfied even if the level of the primary deficit is nonstationary. He uses two lines of arguments. Firstly, he questions the assumption about the constant real rate. Hence, he modifies the test of Hamilton and Flavin (1986) and defines the sustainable budget policy in such a way that the discounted value of public debt converges to zero. He allows for a time-varying real interest rate, discounts the debt series back to the starting period, and applies the ADF-test to the discounted series. He comes to the conclusion that, over the entire period from 1960 to 1982 , U.S. fiscal policy was not sustainable, i.e., it violated the present-value budget constraint. ${ }^{7}$ Secondly, he asks whether the sustainability of fiscal policy exhibits significant structural breaks and splits the sample into two sub-samples: the pre 1974- and post 1974-sub-periods. He finds that fiscal policy of the U.S. federal government was not sustainable in the second sub-period.

An equivalent to Намilton and Flavin's (1986) test for intertemporal budget constraint requires co-integration between public debt and the budget deficit, given that these series are of the same order of integration. In order to derive a testable hypothesis that equation (3) holds, MACDONALD (1992) starts with relation (2b), takes expected values, substitutes $S$ for the primary deficit, $S_{t}=G_{t}-R_{t}$, and after rearranging gets

$$
T D_{t}-\frac{1}{r} S_{t}=E_{t}\left[\sum_{\tau=t+1}^{\infty} \frac{\Delta S_{\tau}}{(1+r)^{\tau-1}}\right] .
$$

Condition (7) implies that the test for stationarity of $\Delta S$ is equivalent to the test for stationarity of $\left(T D_{t}-S_{t} / r\right)$. Thus, the sustainability condition requires the co-integration between $S$ and $T D$ with the co-integrating vector $[1-r]$. To test this hypothesis, MACDonald (1992) employs U.S. quarterly data for the period 
from 1951 to 1984. Applying the co-integration methods of ENGLE and Granger (1987) and Johansen (1988), he fails to find evidence for co-integration and concludes that the U.S. budget deficit was not consistent with the intertemporal budget constraint. Like WILCOX (1989), he assumes the presence of structural breaks and performs his analysis also for different sub-samples. He concludes that U.S. fiscal policy violated the present-value budget constraint in the sub-samples as well. The same result was reached by TREHAN and WALSH (1988) with an alternative test for the intertemporal budget constraint, based on the co-integration between the deficit and public debt with annual data from 1946 to 1987.

HaккIO and Rush (1991) propose to rewrite equation (2b) with total expenditure on the left-hand side:

$$
\begin{aligned}
T G_{t} & =G_{t}+r T D_{t-1} \\
& =R_{t}+\sum_{\tau=t}^{\infty}\left[\frac{1}{(1+r)^{\tau-t-1}}\left(\Delta R_{\tau}-\Delta G_{\tau}\right)\right]+\lim _{T \rightarrow \infty} \frac{1}{(1+r)^{T-\tau}} \Delta T D_{T} .
\end{aligned}
$$

They assume that revenues $R$ and expenditures $G$ are integrated of order 1, so that $\Delta R$ and $\Delta T G$ are stationary, and rearrange equation (8) to

$$
T G_{t}=\alpha+R_{t}+\lim _{T \rightarrow \infty} \frac{1}{(1+r)^{T-\tau}} T D_{T}+\varepsilon_{t} .
$$

Assuming that the limit term in (8) goes to zero leads to the test equation

$$
R_{t}=\alpha+\beta T G_{t}+\varepsilon_{t}
$$

Given that $T G$ and $R$ are both difference-stationary, Hakkio and RusH (1991) define cointegration between these variables as a necessary condition for the present-value budget constraint to hold. Furthermore, they show that $0<\beta \leq 1$ is a necessary condition for the term in (9) to go to zero.

To test these hypotheses, HAKKIO and RusH (1991) use U.S. quarterly data for the period from the second quarter of 1950 to the last quarter of 1988. They show that revenues and expenditures are co-integrated, but that the cointegration coefficient $\beta$ is significantly lower than one. Furthermore, they find that the budgetary process exhibits a significant structural shift. When using the sample from 
1964 to 1988 , they show that the federal budget deficit violates the present-value budget constraint. HAUG (1995) comes to the same conclusion when applying the same approach to quarterly data for the period from 1950 to $1990 .{ }^{8}$

Using a similar methodology, Quintos (1995) introduces 'strong' and 'weak' conditions for intertemporal budget balance. Starting with regression equation (10), she defines that (i) 'strong' sustainability requires the co-integration between expenditures and revenues with the co-integrating vector [1-1], while (ii) 'weak' sustainability involves co-integration with $0<\beta<1$; and the budget deficit is not sustainable if $\beta \leq 0$.

To show the rational of these conditions, she reformulates equation (4) in terms of first differences as

$$
T D_{t}=\lim _{T \rightarrow \infty} \frac{1}{(1+r)^{T-t+1}} \Delta T D_{T}=0
$$

Assuming a constant interest rate $r$, and under the condition that $\triangle T D$ is a stationary process, she derives the trajectory of the limit term in (11) depending on stochastic characteristics of $\triangle T D$. If this is stationary, the evolution of the term at the limit behaves like

$$
E_{t}\left[\lim _{T \rightarrow \infty} e^{-\lambda T}\right]=0
$$

where $\lambda$ is a constant $(\lambda \geq 0)$. If $\Delta T D$ is nonstationary, then this term behaves like

$$
E_{t}\left[\lim _{T \rightarrow \infty} e^{-\lambda T} \sqrt{T}\right]=0
$$

She shows that the stationarity of $\triangle T D$ is a sufficient condition for the term in (11) to go to zero. Furthermore, the term in (12) goes faster to zero than the one in (13) when revenues and expenditures are not cointegrated. She proposes (12) as the 'strong' and (13) as the 'weak' condition for fiscal sustainability. As the term in (13) tends slower to zero, Quintos (1995) suggests that the condition 
for intertemporal budget balance is fulfilled, but that the government might face difficulties in managing its debt because $0<\beta<1$ is a sufficient condition for (13) to be valid.

In order to derive a testable hypothesis, Quintos (1995) starts with regression equation (10). Given that the residuals from the cointegrating regression are $\mathrm{I}(0)$, if revenues $R$ and expenditures $T G$ are cointegrated, she inserts (10) into equation (1), and obtains the equation of undiscounted public debt after rearranging as

$$
\Delta T D_{t}=(1-\beta) T G_{t}-\alpha+\varepsilon_{t} .
$$

She shows that, if $0<\beta<1$ in (14), $\Delta T D$ is like $T G$ nonstationary, regardless of whether $R$ and $T G$ are cointegrated. Accordingly, both conditions, (i) $\beta=1$ and (ii) cointegration between $R$ and $T G$, are together necessary and sufficient for (11) to hold.

Using U.S. quarterly data over the period from 1947 to 1992, Quintos (1995) finds that $0<\beta<1$ holds in the estimated model (10), and she concludes that the U.S. budget deficit is 'weakly' sustainable for the entire sample.' However, when testing for a structural break, she finds such a break at the beginning of the eighties. Taking this into account, she finds that revenues and expenditures are co-integrated with a cointegrating vector $[1-1]$ in the first sub-period, but are not co-integrated while $0<\beta<1$ in the second sub-period. Thus, the U.S. deficit is weakly sustainable in any case.

The discussion of the previous empirical studies suggests that the analysis of sustainability produces different results depending on the methods used. In this study, we apply tests for cointegration between revenues and expenditures in order to test for sustainability of the Swiss federal budget deficit over the period from 1900 to 2002. In doing so, we follow the econometric methodology of Quintos (1995). We use the definition of strong sustainability when revenues and expenditures are cointegrated with the cointegrating vector $[1-1]$ and assume that the budget process is weakly sustainable for $0<\beta<1$. Furthermore, since the data covers World Wars and the Great Depression, which as exogenous shocks may be relevant to fiscal sustainability, we adopt tests for co-integration, which are robust to structural breaks. We apply the Chow-stability test to estimate structural breaks in the short-run relationship as proposed by STOCK and WaTsON

9 Martin (2000) performs this co-integration test by using an international data set. 
(1993). Hence, additionally, we use the modified cointegration test of GrEGORY and HANSEN (1996) which allows for structural breaks in the parameters of the long-run relationship.

In one important respect, however, we deviate from the methodologies used in these more recent studies and go back to the original idea of Domar (1944): For the fiscal data, we use ratios to GDP instead of the original real variables. There are two reasons for doing so. First, as mentioned above, this corresponds to a more natural definition of sustainability. Second, when taking real values, most of the conditions given above are only sufficient but not necessary for sustainability. For example, if there is a common stochastic trend in GDP on the one and public debt and the deficit on the other hand, stationarity of the latter two is not necessary for a sustainable fiscal policy. Thus, the corresponding conditions of HAMILTON and Flavin (1986) are too strong. On the other hand, the ratios of these two variables with GDP should be stationary. It is possible to use ratios instead of the original real variables as the calculations above also hold if we substitute G, R and TD by their ratios to GDP and $r$ by the difference between the interest and the economic growth rates. ${ }^{10}$

\section{Empirical Results}

We use annual fiscal data of the Swiss Federal Government for the period from 1900 to 2002. The data are taken from the Historical Statistics of Switzerland, and from several issues of the Statistical Yearbook of Switzerland and the Federal Budget. They were obtained from the Federal Statistical Office and the Swiss National Bank, as well as other complementary sources. The series include federal non-interest expenditures, interest payments, military and non-military expenditures, revenues and federal debt and real gross national product (GDP). ${ }^{11}$

\subsection{Results of Unit Root and Stationarity Tests}

We first examine the stationarity properties of the series by using the Augmented Dickey-Fuller (ADF) and the Phillips-Perron (PP) tests. We also perform the Kwiatkowski, Phillips, Schmidt and Shin ( 1992) (KPSS) test which has

10 One might argue that shares can hardly be nonstationary. On the other hand, the question is not whether they are stationary or nonstationary but whether the sample at stake is more appropriately described by a stationary or nonstationary data generating process. See for this, for example, KirchgäsSNER and Wolters (2007, p. 193 f.).

11 The sources of the data are given in the Appendix. 
the stationarity of the time series as null hypothesis. We perform these different procedures since the results are sensitive to the use of the long-run variance estimators if the time series are highly autocorrelated. ${ }^{12}$ We apply unit root and stationarity tests to the variables in levels and first differences. The results are given in Table 1.

If time series have significant structural breaks, the power of standard unit root tests decreases substantially. To take this into account, we split the entire sample into two sub-samples, from 1900 to 1939 and from 1946 to 2002 by eliminating the observations during World War II, and perform unit root and stationarity tests for the pre- and post-World War II sub-periods. The results for these two sub-periods are also given in Table 1.

For the entire sample, the results of the tests provide evidence for stationarity of the deficit-GDP ratio: the coefficient of the autoregressive term in the ADFregression is -0.233 , with a $t$-statistic of -3.941 . The findings are, however, quite different for the sub-periods. Considering the pre-1939 sub-period, the tests suggest non-stationarity: the coefficient of the autoregressive term is -0.140 with a $t$-statistic of -1.288 . After 1946, the unit root hypothesis is rejected when we use the PP-test, but cannot be rejected when we use the ADF-test. Similar results hold for the primary deficit in relation to GDP, while public debt never seems to be stationary. On the other hand, the first differences of all three series are clearly stationary.

The KPSS test provides similar results. Over the whole period, the hypothesis of stationarity cannot be rejected for all three variables. It can be rejected for the deficits, however, in the first period at the 10 and in the second one at the 5 percent level. For public debt, it can be rejected in the first period at the 5 percent level.

The results for the revenue- and expenditure-ratios are also given in Table 1. They favour the existence of a unit root for revenue and expenditure in levels, but indicate stationarity for their first differences. The stationarity test results are, however, different for the pre- and post-World War II sub-periods; they indicate stationarity before and nonstationarity after World War II.

The difference in the results for the total period on the one and the two subperiods on the other hand indicate that there might be a structural break related to World War II. Thus, in a next step we check whether such breaks affect the stationarity properties of the time series. We treat the year 1943 as the date when changes of the trend function might have happened and apply the Perron (1989) 
Table 1: Tests for Unit Roots and Stationarity

\begin{tabular}{|c|c|c|c|c|c|c|}
\hline \multirow[b]{2}{*}{ Variables } & \multicolumn{2}{|c|}{ ADF test } & \multicolumn{2}{|c|}{ PP test } & \multicolumn{2}{|c|}{ KPSS test } \\
\hline & Levels & $\begin{array}{c}\text { First } \\
\text { Differences }\end{array}$ & Levels & $\begin{array}{c}\text { First } \\
\text { Differences }\end{array}$ & Levels & $\begin{array}{c}\text { First } \\
\text { Differences }\end{array}$ \\
\hline & \multicolumn{6}{|c|}{$1900-2002$} \\
\hline Public debt & -2.606 & $-5.888^{* *}$ & -1.807 & $-5.826^{* *}$ & 0.296 & 0.115 \\
\hline Primary deficit & $-4.425^{* *}$ & $-9.314^{* *}$ & $-3.456^{*}$ & $-9.305^{* *}$ & 0.112 & 0.028 \\
\hline Total deficit & $-3.941^{* *}$ & $-9.117^{* *}$ & $-3.113^{*}$ & $-9.112^{* *}$ & 0.150 & 0.037 \\
\hline Revenue & -1.115 & $-6.870^{* *}$ & -1.279 & $-15.380^{* *}$ & $1.688^{* *}$ & 0.050 \\
\hline Expenditure & -2.483 & $-6.267^{* *}$ & -2.140 & $-6.296^{* *}$ & $1.009^{* *}$ & 0.038 \\
\hline Military expenditure & $-4.218^{* *}$ & $-4.892^{* *}$ & $-3.124^{*}$ & $-6.778^{* *}$ & 0.163 & 0.042 \\
\hline \multirow[t]{2}{*}{ Civil expenditure } & -1.266 & $-5.021^{* *}$ & -1.131 & $-9.012^{* *}$ & $1.594^{* *}$ & 0.044 \\
\hline & \multicolumn{6}{|c|}{ 1900-1939 } \\
\hline Public debt & -0.947 & $-3.929^{* *}$ & -0.855 & $-3.930^{* *}$ & $0.728^{*}$ & 0.085 \\
\hline Primary deficit & -1.635 & $-5.174^{* *}$ & -1.806 & $-5.168^{* *}$ & $0.129^{(*)}$ & 0.143 \\
\hline Total deficit & -1.288 & $-4.980^{* *}$ & -1.470 & $-4.989^{* *}$ & $0.178^{(*)}$ & 0.143 \\
\hline Revenue & -0.310 & $-9.694^{* *}$ & -0.393 & $-11.120^{* *}$ & 0.853 & 0.112 \\
\hline Expenditure & -0.257 & $-2.901^{(*)}$ & -0.373 & $-2.822^{(*)}$ & 0.522 & 0.174 \\
\hline Military expenditure & -2.314 & -2.109 & -1.591 & $-3.699^{(*)}$ & 0.096 & 0.158 \\
\hline \multirow[t]{2}{*}{ Civil expenditure } & -0.789 & -4.898 & -1.029 & $-4.910^{* *}$ & 0.719 & 0.059 \\
\hline & \multicolumn{6}{|c|}{$1946-2002$} \\
\hline Public debt & -1.627 & $-3.798^{* *}$ & $-3.382^{*}$ & $-6.454^{* *}$ & 0.337 & $0.863^{*}$ \\
\hline Primary deficit & -2.511 & $-11.787^{* *}$ & $-3.579^{* *}$ & $-12.502^{* *}$ & $0.695^{*}$ & 0.067 \\
\hline Total deficit & -2.223 & $-11.573^{* *}$ & $-3.547^{*}$ & $-12.033^{* *}$ & $0.492^{*}$ & 0.065 \\
\hline Revenue & -1.477 & $-4.384^{* *}$ & $-3.598^{* *}$ & $-12.766^{* *}$ & $0.594^{* *}$ & $0.486^{*}$ \\
\hline Expenditure & -1.824 & $-9.043^{* *}$ & -2.069 & $-9.426^{* *}$ & $0.845^{* *}$ & $0.483^{*}$ \\
\hline Military expenditure & 0.136 & $-5.846^{* *}$ & -0.859 & $-7.445^{* *}$ & $1.020^{* *}$ & 0.147 \\
\hline Civil expenditure & -0.151 & $-8.411^{* *}$ & -1.369 & $-8.292^{* *}$ & $0.905^{* *}$ & $0.514^{*}$ \\
\hline
\end{tabular}

The values are the estimated t-statistics. '**', '*' or '(*)' show that the corresponding null hypothesis can be rejected at the 1,5 , or 10 percent level, respectively. The number of lags of the ADF test has been determined using the Hannan-Quinn criterion. For the PP and the KPSS tests always 4 lags have been used. 
test to the variables defined in terms of GDP-ratios. ${ }^{13}$ We estimate three models. Model (A) allows for one-time shift in the intercept of the trend function and is defined by

$$
\Delta y_{t}=\alpha_{0}+\alpha_{1} y_{t-1}+\beta_{1} \Delta y_{t-1}+\ldots+\beta_{n} \Delta y_{t-n}+\gamma D\left(T B_{t}\right)+\varepsilon_{\mathrm{t}},
$$

where the dummy variable $D(T B)=1$ for $t=1943$ and 0 elsewhere.

Model (B) accounts for a possible change in the trend function and is defined by

$$
\Delta y_{t}=\alpha_{0}+\alpha_{1} y_{t-1}+\beta_{1} \Delta y_{t-1}+\ldots+\beta_{n} \Delta y_{t-n}+\delta D U_{t}+\varepsilon_{\mathrm{t}}
$$

where the dummy variable $D U_{t}=1$ for $t>1942$ and 0 elsewhere.

Finally, model (C) allows for a change in the intercept as well as the growth rate:

$$
\Delta y_{t}=\alpha_{0}+\alpha_{1} y_{t-1}+\beta_{1} \Delta y_{t-1}+\ldots+\beta_{n} \Delta y_{t-n}+\gamma D\left(T B_{t}\right)+\delta D U_{t}+\varepsilon_{\mathrm{t}} .
$$

The results of the Perron test are given in Table 2. They are quite similar to those in the first part of Table 1 where the whole period from 1900 to 2002 was considered. While public debt, revenue and expenditure are nonstationary, the primary and the total deficit are stationary. ${ }^{14}$ Both results hold regardless of whether we assume that World War II caused a break in the generating processes of the series or not. ${ }^{15}$ As there might be more than one break in the data, we also applied the Lagrange multiplier (LM) test, proposed by LeE and STRAZicich (2003), to take account of two breaks with unknown dates. The results given in the Appendix are also quite in line with the results of the standard unit root and stationarity tests. At least some of the endogenously determined dates, however, seem hardly plausible. Nevertheless, the differences in the results between the whole period and the two sub-periods remain and do not seem to be caused by structural breaks.

13 The Perron test is also performed for a break-point in the year 1946. The results are quite similar.

14 Critical values for the unit root test are from Perron (1989) for $\lambda=0.4$, which is the ratio of the number of observations in the pre-World War II sub-period to the total number of observations in the sample.

15 We get similar results if we assume that the break took place in 1944, 1945 or 1946. 
Table 2: Unit Root Tests with a Structural Break in 1943

\begin{tabular}{lcc|cc|cc}
\hline Variables & \multicolumn{2}{c|}{ Model A } & \multicolumn{2}{c|}{ Model B } & \multicolumn{2}{c}{ Model C } \\
& $k$ & \multicolumn{1}{c|}{$k$} & $k$ & $\hat{t}$ & $k$ & $\hat{t}$ \\
\hline Public debt & 4 & -1.825 & 0 & -2.465 & 0 & -1.371 \\
Revenues & 3 & -0.314 & 6 & -1.386 & 3 & -0.489 \\
Expenditure & 1 & -2.863 & 1 & -2.612 & 1 & $-3.495^{*}$ \\
Primary deficit & 4 & $-4.441^{* *}$ & 4 & $-4.414^{* *}$ & 4 & $-4.612^{* *}$ \\
Total deficit & 4 & $-3.956^{*}$ & 4 & $-4.442^{* *}$ & 4 & $-3.670^{*}$ \\
\hline
\end{tabular}

All variables are measured in relation to GDP. '**), '*) or $^{(* *)}$ ' show that the null hypothesis of no cointegration can be rejected at the 1,5 , or 10 percent level, respectively. $-\mathrm{k}$ is the number of lags.

\subsection{Results of Engle-Granger Cointegration Tests}

Given that the unit root test results for the whole period indicate stationarity of deficit-GDP ratio, and difference-stationarity of the revenue- and expenditureratios with the same order of integration, the next step is to test for co-integration between revenues and expenditures. By performing this analysis we test two hypotheses: (i) whether the revenue- and expenditure-GDP ratios are co-integrated, and (ii) whether the co-integrating vector (excluding the constant term) is close to $[1-1]$. One possibility is to use the residual-based test of ENGLE and GRANGER (1987) for co-integration, which is based on the ordinary least squares (OLS) residuals $\hat{\varepsilon}_{t}$ from the co-integrating regression of model (9).

The results for the whole period including and excluding the years of the two World Wars as well as the results for the two sub-periods are given in Table 3. ${ }^{16}$ The ADF-test gives a $t$-statistic of -3.120 , which is significant at the 10 percent level. This indicates that federal revenue- and expenditure-GDP ratios are co-integrated when we use the full sample. However, the Jarque-Bera statistics indicate that the residuals are not normally distributed. Excluding the years that may be viewed as outliers we check whether the estimated co-integrating vector is consistent with the theoretical prediction. ${ }^{17}$ In this case, the co-integrating vector is [ $1-0.999]$. This suggests that the federal budget deficit is sustainable over the entire period.

16 Critical values for the ADF-test are taken from MacKinnon (1991) and for the DurbinWatson statistic from EnGLE and Granger (1987). To check the robustness of the results, we performed the calculations in both directions.

17 We exclude the years 1919 to 1921 as well as 1939 to 1946 from the sample. 
Table 3: Results of the Engel-Granger Cointegration Test

\begin{tabular}{|c|c|c|c|c|c|c|}
\hline \multirow[b]{2}{*}{ Dependent variable } & \multicolumn{3}{|c|}{ Cointegrating equation } & \multicolumn{3}{|c|}{ Residual regression } \\
\hline & $\hat{\beta}$ & $\mathrm{R}^{2}$ & D.-W. & $k$ & $\begin{array}{c}\mathrm{ADF} \\
\text { statistic }\end{array}$ & $\begin{array}{c}\mathrm{PP} \\
\text { statistic }\end{array}$ \\
\hline & \multicolumn{6}{|c|}{$1900-2002$} \\
\hline Expenditure-GDP-ratio & $\begin{array}{c}0.710 \\
(0.12)\end{array}$ & \multirow{2}{*}{0.741} & $0.364^{(*)}$ & 0 & $-3.120^{(*)}$ & $-3.012^{(*)}$ \\
\hline \multirow[t]{2}{*}{ Revenue-GDP-ratio } & $\begin{array}{l}1.042 \\
(0.12)\end{array}$ & & $0.359^{(*)}$ & 0 & $-3.147^{(*)}$ & $-3.398^{*}$ \\
\hline & \multicolumn{6}{|c|}{ 1900-1913, 1922-1939, 1946-2002 } \\
\hline Expenditure-GDP-ratio & $\begin{array}{c}0.999 \\
(0.03)\end{array}$ & \multirow{2}{*}{0.927} & $0.730^{* *}$ & 1 & $-3.622^{*}$ & $-4.577^{* *}$ \\
\hline \multirow[t]{2}{*}{ Revenue-GDP-ratio } & $\begin{array}{r}0.927 \\
(0.03)\end{array}$ & & $0.747^{* *}$ & 1 & $-3.380^{*}$ & $-4.374^{* *}$ \\
\hline & \multicolumn{6}{|c|}{ 1900-1939 } \\
\hline Expenditure-GDP-ratio & $\begin{array}{c}0.498 \\
(0.10)\end{array}$ & \multirow{2}{*}{0.408} & $0.372^{(*)}$ & 0 & -2.010 & -1.860 \\
\hline \multirow[t]{2}{*}{ Revenue-GDP-ratio } & $\begin{array}{r}0.817 \\
((0.16) \\
\end{array}$ & & $0.400^{*}$ & 0 & -1.403 & -1.552 \\
\hline & \multicolumn{6}{|c|}{$1946-2002$} \\
\hline Expenditure-GDP-ratio & $\begin{array}{c}0.726 \\
(0.08)\end{array}$ & \multirow{2}{*}{0.734} & $0.964^{* *}$ & 2 & $-3.782^{*}$ & $-4.967^{* *}$ \\
\hline Revenue-GDP-ratio & $\begin{array}{c}1.009 \\
(0.06)\end{array}$ & & $0.732^{* *}$ & 1 & -2.554 & $-3.587^{*}$ \\
\hline
\end{tabular}

‘**, '*’ or '(*)' show that the null hypothesis of no cointegration can be rejected at the 1,5 , or 10 percent level, respectively. $-\mathrm{k}$ is the number of lags of the ADF test.

The results are again different if we look at the two sub-periods. In the pre-World War II sub-period, the revenue- and expenditure-GDP ratios do not seem to be co-integrated; when taking expenditure as the dependent variable, the $t$-statistic is only -2.010 . Similar results are obtained from the reversed regression: the $t$-statistic of -1.403 is not significant at any conventional significance level. This lends further support to the findings of the unit root and stationarity tests. After World War II, the two variables are cointegrated, as the ADF statistic with expenditure as the dependent variable suggests. However, the estimated co-integrating vector of $[1-0.726]$ indicates that the federal budget was hardly balanced. Thus, while we find no evidence at all for the first sub-period, we find evidence for weak sustainability in the post-World War II period. 


\subsection{Results of Tests for Structural Breaks in the Long-Run Relationship}

To take account of possible shifts in the parameters of the co-integrating vector, we follow Gregory and Hansen (1996) and use the test for stability of the estimated coefficients by allowing for a one-time structural change in the deficit generating process. To check for the effects of structural breaks, we perform Chow-tests for the null hypothesis of a constant cointegrating relation against the alternative of different cointegrating vectors in the pre-and post-World War II sub-periods. We apply this test to the dynamic ordinary least-squares regression using two lags and assuming an AR(4) error process. ${ }^{18}$ The results are shown in Figure $3{ }^{19}$ They show that the null hypothesis of no break can be rejected at all conventional significance levels at several points during the World War II sub-period.

Figure 3: Values of the Chi-Squared Test for Parameter Stability in the Cointegrating Vector

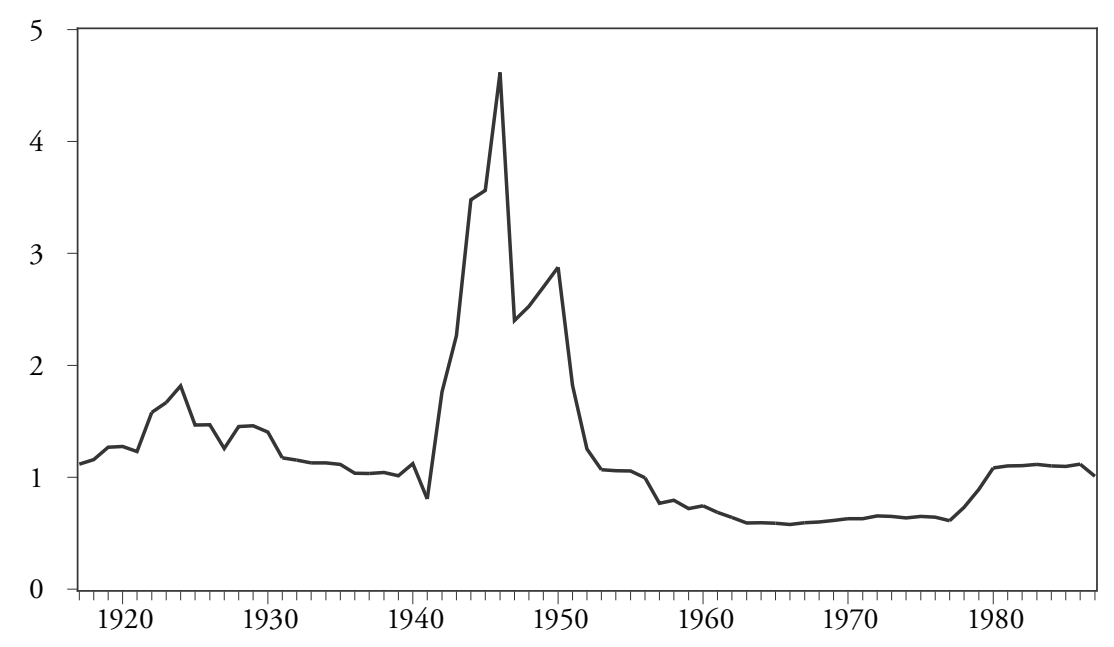

18 See for this Stock and Watson (1993). Using a similar test, Hakкio and Rush (1991) and HAUG (1995) show that the date of the break-points has a significant effect on the results for the sustainability of the U.S. federal deficit. Quintos (1995) arrives at the same conclusion by applying the modified Wald-test.

19 Following the suggestion of Andrews (1993), we perform the tests only for the trimmed sample by eliminating the initial and the final 15 percent of the observations. 
Based on this evidence, in the following analysis we treat World War II as a shock which significantly changes the parameters of the co-integrating regression. To examine the question of whether this break-point has a significant effect on the intertemporal budget balance, we perform the Gregory and Hansen (1996) modified co-integration test. This evidence concerns the properties of the cointegrating residuals which are different for the pre- and post-World War II subperiods.

Gregory and Hansen (1996) offer three models that allow for correcting the co-integrating relationships in the presence of structural break-points. Assuming a break-point in the year 1940, the first model (A) which accounts for the level shift in the co-integrating relationships is given by

$$
R_{t}=\alpha+\beta_{1} T G_{t}+\beta_{2} D U_{t}+\varepsilon_{t},
$$

where the dummy variable $D U_{t}=1$ for $t>1940$ and zero elsewhere.

The second model (B) includes a time trend

$$
R_{t}=\alpha+\beta_{1} T G_{t}+\beta_{2} D U_{t}+\beta_{3} t+\varepsilon_{t} .
$$

A third model (C) allows for a regime shift in the co-integrating regression coefficient

$$
R_{t}=\alpha+\beta_{1} T G_{t}+\beta_{2} D U_{t}+\beta_{3}\left(D U_{t} \cdot T G_{t}\right)+\varepsilon_{t},
$$

where $(D U \cdot T G)$ represents a regime shift in the deficit generating process. We apply the ADF-test to the residuals from each of the estimated co-integrating models (16) to (16") to assess our null hypothesis. The critical values are from Gregory and Hansen (1996).

Figure 4 depicts the $\operatorname{ADF}(\tau)$-statistics of the residuals from each of three estimated co-integrating models (16) to (16") by treating each year in the interval $[(0.15 T),(0.85 T)]$ as a break-point. The figure illustrates that significant ADFvalues are estimated for several break- points during the pre-World War II subperiod: these findings confirm the assumption of non-sustainability of budget deficit over this time period. 
Figure 4: Test Statistics of the ADF-Test for Cointegration between Federal Revenue-GDP and Expenditures-GDP Ratios

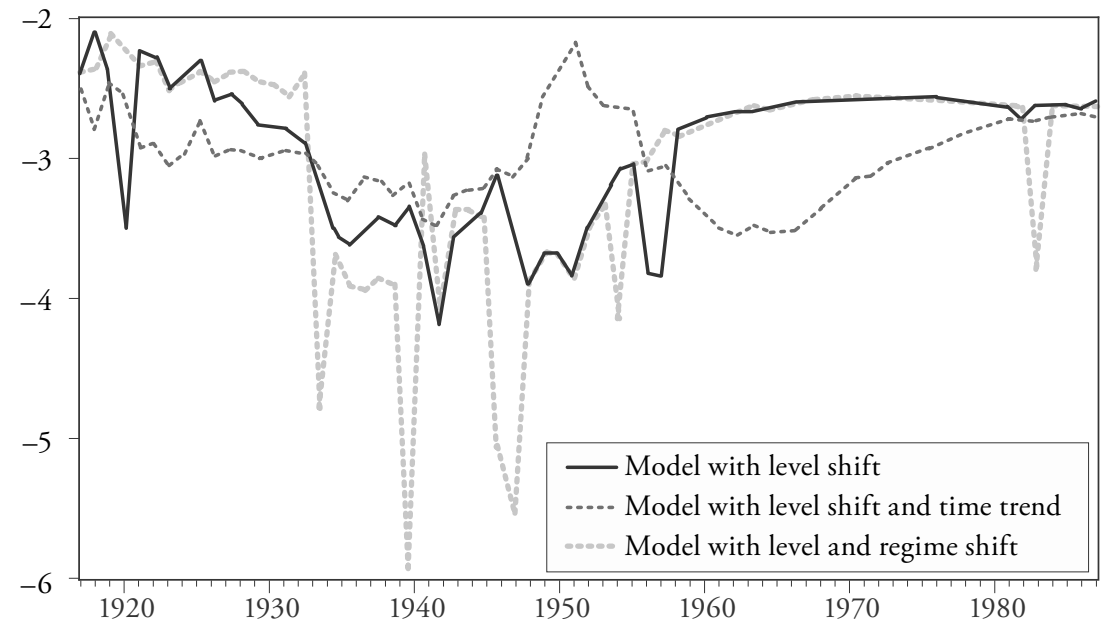

\subsection{Results of Johansen Cointegration Test}

In addition to the ADF-test, we also use the JoHANSEN (1988) multivariate cointegration test in order to determine the number of co-integrating vectors in the system. We perform the trace test as well as the maximum eigenvalue test, and we assume that there is a constant in the error-correction-term. The lag length of the VAR is selected by using the Schwarz criterion. Critical values are taken from Osterwald-Lenum (1992).

Table 4 shows the results for the entire sample and for the two sub-periods from 1900 to 1939 and from 1946 to 2002. These results support the hypothesis of co-integration between revenues and expenditures as shares of GDP, with a cointegrating vector of [ $1-1.045]$ for the entire sample; the findings are economically reasonable. ${ }^{20}$ The evidence for the sub-periods is also quite in line with the previous results. The null hypothesis of no cointegration cannot be rejected for the shares of revenues and expenditures of GDP-ratio in the pre World War II period, but the coefficient of the cointegrating equation is quite close to 1 . They are co-integrated with a cointegrating vector of [ $1-0.783]$ for the post-World

20 None of the estimated constants is significantly different from zero. Thus, they can be neglected. 
War II period. The value of the $\chi^{2}$ test statistic for the hypothesis that the cointegrating vector is $[1-1]$ is 0.22 with a $p$-value of 0.63 . The coefficient of the cointegrating equation is quite close to the estimated coefficient $\hat{\beta}=0.726$ in the static regression of the ENGLE and Granger (1987) test.

Table 4: Results of the Johansen Cointegration Test

\begin{tabular}{|c|c|c|c|c|c|}
\hline Eigenvalue & $\begin{array}{c}\text { Null } \\
\text { hypothesis }\end{array}$ & Lags & $\begin{array}{c}\text { Trace } \\
\text { statistic }\end{array}$ & $\begin{array}{c}\text { Maximum } \\
\text { eigenvalue } \\
\text { statistic }\end{array}$ & $\begin{array}{c}\text { Normalised } \\
\text { cointegration } \\
\text { vector (with- } \\
\text { out constant) }\end{array}$ \\
\hline \multicolumn{6}{|c|}{ 1900-2002 } \\
\hline 0.214 & $r=0$ & 4 & $27.91^{* *}$ & $23.70^{* *}$ & {$[1.0-1.045]$} \\
\hline 0.042 & $r=1$ & 4 & 4.21 & 4.21 & \\
\hline \multicolumn{6}{|c|}{ 1900-1939 } \\
\hline 0.215 & $\mathrm{r}=0$ & 1 & 11.96 & 9.21 & {$[1.0-1.070]$} \\
\hline 0.069 & $\mathrm{r}=1$ & 1 & 2.74 & 2.74 & \\
\hline \multicolumn{6}{|c|}{ 1946-2002 } \\
\hline 0.497 & $r=0$ & 4 & $40.74^{* *}$ & $39.20^{* *}$ & {$[1.0-0.783]$} \\
\hline 0.026 & $\mathrm{r}=1$ & 4 & 1.54 & 1.54 & \\
\hline
\end{tabular}

Taking all results together, the federal budget deficit is consistent with the intertemporal budget constraint if we consider the entire period where federal revenues and expenditures are cointegrated with a cointegrating vector close to $[1-1]$. When using the two sub-samples, the results again show that the intertemporal budget constraint might be violated for the pre-World War II period, while the weak sustainability condition may hold in the post-World War II period. 


\section{Concluding Remarks}

This study asks whether fiscal policy of the Swiss Federation is sustainable. We consider the period from 1900 to 2002, but - allowing for a structural break in relation to World War II - also the two sub-periods from 1900 to 1939 and from 1946 to 2002. Using annual data, we perform several unit root and stationarity tests as well as tests for co-integration between the revenue- and expenditureGDP ratios. All tests provide more or less the same picture which is, however, in itself contradictory. Considering the whole period, the estimated results suggest that the federal fiscal policy is sustainable; the budget deficit is consistent with the intertemporal budget constraint. Revenue- and expenditure-GDP ratios are, for example, cointegrated with a cointegrating vector close to [1 -1]. If we consider the two sub-periods separately, we get, however, quite different results: Swiss fiscal policy does not seem to be sustainable in the first period; and there is only evidence for weak sustainability in the period after World War II.

The question is how to interpret this puzzle. It can hardly be caused by the structural break in relation to World War II, as in this case the opposite result should occur: sustainability for the two sub-periods but no evidence for sustainability over the whole period. An alternative, but also hardly a satisfactory explanation might be that the power of the unit root and cointegration tests is too low to reject the null hypotheses in the sub-periods but might be sufficient to reject them if we consider the whole period.

If we look at the more recent development as shown in Figures 1 and 2, another explanation might be more convincing: even in historical perspective, the large deficits in the federal budget outside war times arose in the last thirty and especially in the last fifteen years. This results in a more or less steady increase of the federal debt since 1975. Thus, even if fiscal policy was sustainable up to the mid seventies of the last century, it might no longer be sustainable in the most recent past. If we consider the whole period, including the war time deficits, these more recent deficits do not seem to be very large, but considering the situation in peace times, they are. This was also the conviction of the Swiss citizens when they accepted the introduction of a debt brake at the federal level in 2001. Such debt breaks have proved to be quite effective in some Swiss cantons like St. Gall and Fribourg, where they were introduced several decades ago, ${ }^{21}$ and the hope is that this institution will bring back federal fiscal policy to a sustainable path. 


\section{Appendix}

\section{A) Data and Sources}

- Federal revenues

- Federal expenditures

- Federal public debt

Sources: Statistisches Jahrbuch der Schweiz, several issues. See also RitzmannBlickenstorfer (1996, pp. 947 ff.).

- Real Gross National Product (GDP)

Sources: Data have been provided by the Swiss Federal Statistical Office. Real GDP data for the period from 1914 to 1947 are from ANDRIST et al. (2000), for the period before 1914 from RitzMANN-BLICKENSTORFER (1996, p. 866).

\section{B) Results of Unit Root Tests with Two Structural Breaks}

Following Lee and Strazicich (2003) and employing a Lagrange multiplier (LM) test, we checked for unit roots under the assumption of two structural breaks. The dates of these breaks are endogenously determined by the minimum of the LM statistic. The alternative hypothesis is that of a trend stationary time series.

The two-break minimum LM unit root test estimates the breakpoints $\left(T_{B j}\right)$ endogenously by utilizing a grid search as follows

$$
L M_{\tau}=\inf _{\lambda} \tilde{\tau}(\lambda)
$$

with $\tilde{\tau}$ being the $t$-statistic for the unit root null hypothesis. The breakpoint is estimated by minimizing the test statistic. As is common for employing this kind of tests, we use the trimming of the infimum over $[k, 1-k]$ for some $k$; here we use 10 percent to eliminate the effect of endpoints on the test results.

We apply the minimum LM unit root test by using the augmented correction for the serial correlation. The number of lagged augmentation terms is determined by using the procedure of $\mathrm{NG}_{\mathrm{G}}$ and Perron (1995). Starting with a maximum number of lags $k=8$, we look for significance of the last augmented term. We consider the 10 percent asymptotic normal value of 1.645 on the $t$-statistic of the last first-differences lagged term. After finding the optimal lag number at each combination of two breakpoints, the breakpoints are defined when the endogenous 
LM t-test statistic is minimized. Thus, we examine each possible combination of two breakpoints over the interval [0.1T, 0.9T]. The results of the tests are depicted in Table 2. At the 1 percent level, the null unit root hypothesis can be rejected for public debt, the primary and total deficit, and military expenditure. On the other hand, revenue and expenditure are difference stationary. This finding is nearly compatible with the results provided by the standard unit root and stationarity tests as well as those of the unit root tests with one structural break. (The critical values for models (A) and (C) are from LeE and STrazicich (2003).)

Table A1: Endogenous Two-Breaks LM Unit Root Test

\begin{tabular}{lcccc}
\hline & & & LM-test & \\
Variables & Model & $k$ & $T_{B j}$ & Test statistic \\
\hline Public debt & C & 4 & 1934 & $-5.73^{* *}$ \\
Primary deficit & C & 1 & 1980 & $-6.21^{* *}$ \\
Total deficit & C & 4 & 1991 & $-6.24^{* *}$ \\
& & & 1937 & $-3.92^{(*)}$ \\
Revenue & A & 2 & 1980 & -2.92 \\
Expenditure & & & 1936 & $-6.34^{* *}$ \\
Military expenditure & A & 8 & 1991 & -3.08 \\
\hline Civil expenditure & C & 1 & 1951 & 1991 \\
\hline
\end{tabular}

‘**, '*’ or ‘(*)' show that the null hypothesis of unit root can be rejected at the 1,5 , or 10 percent level, respectively. $-\mathrm{k}$ is the number of lags.

\section{References}

Ahmed, Shagil and John H. Rogers (1995), "Government Budget Deficits and Trade Deficits. Are Present Value Constraints Satisfied in Long-Term Data?", Journal of Monetary Economics 36, pp. 351-374.

Andrews, Donald W. K. (1993), "Tests for Parameter Instability and Structural Change with Unknown Change Point", Econometrica 61, pp. 821-856. 
Andrist, F., R. G. Anderson and M. M. Williams (2000), "Real Output in Switzerland: New Estimates for 1914-47”, Federal Reserve Bank of St. Louis Review 82, pp. 43-70.

Auerbach, Alan J., Jagadeesh Gokhale and Laurence J. Kotlikoff (1991), "Generational Accounts: A Meaningful Alternative to Deficit Accounting", in: D. Bradford (ed.), Tax Policy and the Economy, Vol. 5, Cambridge (Mass.) 1991, pp. 55-110.

Auerbach, Alan J., Jagadeesh Gokhale and Laurence J. Kotlikoff (1992), "Generational Accounting: A New Approach to Understanding the Effects of Fiscal Policy on Saving", Scandinavian Journal of Economics 94, pp. 303-319. Blanchard, Olivier, Jean-Claude Chouraqui, Robert P. Hagemann and Nicola Sartor (1990), "The Sustainability of Fiscal Policy: New Answers to an Old Question”, OECD Economic Studies 15, pp.7-36.

Blanchard, Olivier (1993), "Suggestions for a New Set of Fiscal Indicators", in: H. Verbon and F. van Winden (eds), The Political Economy of Government Debt, Amsterdam, pp. 307-325.

Borgman, Christoph und Bernd Raffelhüschen (2004), Zur Entwicklung der Nachhaltigkeit der schweizerischen Fiskal-und Sozialpolitik: Generationenbilanzen 1995-2001, Staatssekretariat für Wirtschaft, Bern 2004.

BundesRat (2000), „Botschaft zur Schuldenbremse vom 5. Juli 2000“, BBl 2000-1318, pp. 4653-4726.

Bundesrat (2001), „Zusatzbericht zur Botschaft zur Schuldenbremse vom 10. Januar 2001“, BBl 2001-0022, pp. 2387-2420.

Danninger, Stephan (2002), "A New Rule: The Swiss Debt Brake, International Monetary Fund", Working Paper No. 02/18, January.

Domar, Evsey D. (1944), "The Burden of the Debt and the National Income", American Economic Review 34, pp.798-827.

Eidgenössisches Finanzdepartment (2001), Die Schuldenbremse: Dokumentation, Bern, 2nd edition, September 2001.

Engle, Robert F. and Clive. W. J. Granger (1987), "Cointegration and Error-Correction: Representation, Estimation, and Testing", Econometrica 55, pp. 251-276.

Feld, Lars P. and Gebhard Kirchgässner (2005), "Sustainable Fiscal Policy in a Federal System: Switzerland as an Example”, in: H. Kriesi, P. Farago, M. Kohli und M. Zarin-Nejadan (eds), Contemporary Switzerland: Revisiting the Special Case, Houndmills, pp. 281-296.

Feld, Lars P. and Gebhard Kirchgässner (2008), "On the Effectiveness of Debt Brakes: The Swiss Experience", forthcoming in: J.-E. Sturm und R. Neck (eds), Sustainability of Public Debt, Cambridge (Mass.). 
Gregory, Allan W. and Bruce E. Hansen (1996), "Residual Based Test for Co-Integration in Models with Regime Shifts", Journal of Econometrics 70, pp. 99-126.

Hakkio, Craig S. and Mark Rush (1991), "Is the Budget Deficit Too Large?”, Economic Inquiry 29, pp. 429-445.

Hamilton, James D. and Majorie A. Flavin (1986), "On the Limitations of Government Borrowing: A Framework for Empirical Testing", American Economic Review 76, pp. 808-819.

Haug, Alfred A. (1995), "Has Federal Budget Deficit Policy Changed in Recent Years?”, Economic Inquiry 33, pp. 104-118.

Johansen, Søren (1988), "Statistical Analysis of Cointegration Vectors", Journal of Economic Dynamics and Control 12, pp. 231-254.

Kirchgässner, Gebhard (2005), "Sustainable Fiscal Policy in a Federal State: The Swiss Example”, Swiss Political Science Review 11, pp. 19-46.

Kirchgässner, Gebhard and Jürgen Wolters (2007), Introduction to Modern Time Series Analysis, Berlin et al.

Kommission für KonjunktURfragen (2004), Nachhaltigkeit der öffentlichen Finanzen, Jahresbericht 2004, 383. Mitteilung, Beilage zur Volkswirtschaft, dem Magazin für Wirtschaftspolitik, September.

Kremers, Jeroen J. M. (1988), "The Long-Run Limits of the U.S. Federal Debt", Economics Letters 28, pp. 259-262.

Kremers, Jeroen J. M. (1989), "U.S. Federal Indebtedness and the Conduct of Fiscal Policy", Journal of Monetary Economics 23, pp. 219-238.

Kwiatkowski, Denis, Peter C. B. Phillips, Peter Schmidt and Yongcheol SHIN, "Testing the Null Hypothesis of Stationarity Against the Alternative of a Unit Root", Journal of Econometrics 54, pp. 159-178.

Lee, Junsoo and Mark C. Strazicich (2003), "Minimum Lagrange Multiplier Unit Root Test With Two Structural Breaks", Review of Economics and Statistics 85, pp. 1082-1089.

MacDonald, Ronald (1992), "Some Tests of the Government's Intertemporal Budget Constraint Using U.S. Data”, Applied Economics 24, pp. 1287-1292.

MacKinnon, James G. (1991), "Critical Values for Co-integration Tests", in: R. F. Engle and C. W. J. Granger (eds), Long-Run Economic Relationships, Oxford, pp. 267-276.

Martin, Gael M. (2000), "US Deficit Sustainability: A New Approach Based on Multiple Endogenous Breaks", Journal of Applied Econometrics 15, pp. 83-105.

MülleR, UlRich K. (2005), "Size and Power of Tests of Stationarity in Highly Autocorrelated Time Series”, Journal of Econometrics 128, pp. 195-213. 
Ng, Serena and Pierre Perron (1995), "Unit Root Tests in ARMA Models With Data-Dependent Methods for the Selection of the Truncation Lag", Journal of the American Statistical Association 90, pp. 268-281.

OECD (2002), "Fiscal Sustainability: The Contribution of Fiscal Rules", OECD Economic Outlook 72, December.

Osterwald-Lenum, Michael (1992), "A Note with Fractiles of the Asymptotic Distribution of the Maximum Likelihood Cointegration Rank Test Statistics: Four Cases", Oxford Bulletin of Economics and Statistics 54, pp.461-472.

Quintos, Carmela E. (1995), "Sustainability of the Deficit Process with Structural Shifts", Journal of Business and Economic Statistics 13, pp. 409-417.

Perron, Pierre (1989), "The Great Crash, the Oil Price Shock, and the Unit Root Hypothesis", Econometrica 57, pp. 1361-1401.

Ritzmann-Blickenstorfer, Heiner (ed.) (1996), Historische Statistik der Schweiz, Zürich.

Stock, James H. and Mark W. Watson (1993), "A Simple Estimator of Cointegrating Vectors in Higher Order Integrated Systems", Econometrica 61, pp. 783-820.

Trehan, Bharat and Carl E. Walsh (1988), "Common Trends, Intertemporal Budget Balance, and Revenue Smoothing", Journal of Economic Dynamics and Control 12, pp. 425-444.

Trehan, Bharat and Carl E. Walsh (1991), "Testing Intertemporal Budget Constraints: Theory and Applications to the US Federal Budget and Current Account Deficit", Journal of Money Credit and Banking 23, pp. 206-223.

Wilcox, David W. (1989), "The Sustainability of Government Deficits: Implications of the Present Value Constraint", Journal of Money, Credit and Banking 21, pp. 291-306.

\section{SUMMARY}

We examine whether Swiss federal fiscal policy was sustainable over the period from 1900 to 2002 . We perform unit root and cointegration tests for federal revenues and expenditures, taking into account a structural shift in the budgetary process related to World War II. We find sustainability considering the entire period. However, splitting the sample into two sub-samples before and after World War II, the results do much less support sustainability. 